Information Management and Business Review

Vol. 3, No. 6, pp. 336-344, Dec 2011 (ISSN 2220-3796)

\title{
A Conceptual Model for Explaining Supply Chain Performance in Uganda's SMEs
}

\author{
Benjamin R Tukamuhabwa \\ Makerere University Business School, Kampala-Uganda \\ tukabenjah@yahoo.com
}

\begin{abstract}
This study proposes a conceptual framework, which will be used to conduct an empirical study of supply chain performance in SMEs in Uganda. This conceptual framework was developed from the review of the previous literature. The need for this study arises from the fact that where as SMEs form the back borne of Uganda's economy, they have encountered poor supply chain performance. Previous researchers also indicate that studies in SMEs and their supply chains are limited and that more research is needed regarding the link between marketing and supply chain management. The proposed conceptual framework presupposes a positive relationship between market orientation and supply chain performance with organizational learning, supply chain management strategy, trust and commitment playing mediating roles. It is hoped that this proposed integrative conceptual model will also be used in other future empirical studies.
\end{abstract}

Key words: Market orientation, organizational learning, supply chain management, performance, SMEs

\section{Introduction}

The success of an organization depends heavily upon the success of the supply chain in which it participates as a partner (Zelbst et al; 2009). Cai et al; (2008) also stated that one of the issues that have become critical for gaining competitive advantages for companies is improving supply chain performance. As contemporary firms recognize that they can no longer effectively compete in isolation of their suppliers and other entities in the supply chain, they have shifted their attention from competition between firms to competition between the entire supply chains (Hult et al; 2007; Ntayi et al; 2009; Miguel et al; 2010). According to Zelbst et al; (2010), supply chain performance focuses on the ability of the supply chain to satisfy the needs of the ultimate customers of the supply chain. Supply chain inefficiency has been identified as one of the most prevalent issues facing the small- to mid-size enterprise (SMEs) (Lewis, 2005).

Although it is necessary to know the functioning of supply chains in developing countries, there is scanty knowledge about them(Ntayi et al; 2009). Min and Mentzer (2000) recommended empirical studies on market orientation and supply chain management. Green et al (2006) also agitated for more research, which incorporates supply chain performance in the relationship between market orientation and supply chain management strategy. Ju"ttner et al; (2010) indicated that market orientation influences supply chain performance. Vieira, (2010) argues that market orientation influences organizational learning while Miguel et al; (2010) maintained that knowledge sharing and learning positively influence supply chain performance. Ferry et al (2007) also stipulated that trust and commitment influence supply chain performance. Farrelly and Quester (2003) argue that there is little empirical research that examines the effects of marketing orientation on trust and commitment. Antony and Bhattacharyya, 2010; Thakkar et al; 2008) also realized the scantiness of research studies in SMEs and called for more studies. The above research gaps indicate a dire need for this study to provide a detailed investigation of how marketing orientation can be used to enhance supply chain performance of SMEs in the Ugandan context. In Uganda, SMEs compose $90 \%$ of the private sector and contribute 75\% of the Gross Domestic Product (Eyaa and Ntayi, 2010). Unfortunately, the majority of these SMEs die within their first five years and only $5 \%$ to $10 \%$ survive and reach maturity (Private Sector Foundation Uganda, 2006).Besides the importance of SMEs in Uganda's economy, their supply chain performance is problematic (Ntayi et al; 2009). When a firm encounters supply chain performance failure, it is out competed and is likely to collapse (Eyaa and Ntayi, 2010). SME supply chains in Uganda are characterized by late deliveries, poor quality products or no deliveries at all, which are indicators of poor supply chain performance (Ntayi and Eyaa, 2010). 
Although today's competition has shifted from between firms to their entire supply chains (Hult et al; 2007; Ntayi et al; 2009; Miguel et al; 2010), supply chain performance in Uganda's SMEs is still problematic(Ntayi et al; 2009). To enhance supply chain performance, there is need to understand the functioning of the supply chain. Unfortunately, there is scanty knowledge about supply chain management and performance in Uganda. Given the crucial role of SMEs to economies of both developed and developing countries (Antony and Bhattacharyya, 2010; confederation of Tanzanian industries 2009), the supply chain management of SMEs should be subjected to detailed investigation, as implementing supply chain management enhances their competitiveness (Thakkar et al; 2008; Gunasekaran et al; 2004;.Calipinar 2007; Hult et al; 2007). Despite this, SMEs in less developed economies and Uganda in particular have faced various challenges relating to their supply chains. Included among them is inadequate marketing (Onugu, 2005; Hamisi, 2011). Besides, studies in SMEs and their supply chain management are limited and previous researchers have agitated for more research in this area (Quayle, 2003; Antony and Bhattacharyya 2010; Thakkar et al; 2008).Min and Mentzer (2000) also advocated for more empirical research on marketing and supply chain management. Green et al; (2006) advocated for more research on market orientation, supply chain management strategy and supply chain performance. Farrelly and Quester (2003) stated that, there is little empirical research that examines the effects of marketing orientation on trust and commitment while Fawcett et al; (2006) also added that little has been written concerning the commitment levels among those involved in the supply chain. Given that there are limited studies on market orientation, supply chain management strategy, trust, commitment and supply chain performance in less developed countries particularly Uganda, this study will partly fill the gap by investigating market orientation, supply chain management strategy, trust, commitment and supply chain performance in SMEs in the Ugandan context

Theoretical background: This study borrows from the theory of the Resource Based View (RBV) of the firm. This theory advances that resources internal to the firm are sources of competitive advantage. Such resources should be rare, valuable, inimitable and difficult to substitute. Previous researchers argue that intangible assets such as knowledge management, organizational learning and market orientation allow an organization to develop those abilities that enhance competitive advantage leading to superior market performance (Day, 1984). Tan et al; (2011) also identified market orientation as one of the organization capabilities. According to Lennon and Wollin (2001), organizational learning is more difficult to duplicate or imitate. Manuel et al; (2006) maintain that a close relationship with a high level of trust and commitment between companies is necessary to develop relational capabilities. Basing on the RBV of the firm, this study considers market orientation and organizational learning, as intangible organizational resources that enhance supply chain management strategy. We also regard trust and commitment as relational capabilities that can be exploited to boost supply chain performance (Tukamuhabwa et al; 2011).

\section{Literature Review}

Hypotheses development: Market orientation and organizational learning: Slater and Narver (1995) defined organizational learning as the acquisition, interpretation and dissemination of the organizational information inside the firms' culture. These authors also argue that market orientation and organizational learning are inseparable. As cited in Hult et al (2003), there are four dimensions of organizational learning according to Hult (1998) and Hult et al (2000) which include team orientation, systems orientation, learning orientation and memory orientation. Market orientation on the other hand consists of customer orientation, competitor orientation and inter-functional coordination (Narver and Slater 1990). Similarly, Hurley and Hult (1998) supported the association between market orientation and learning, while Vieira (2010) also revealed that market orientation has a strong impact on organizational learning. Min and Mentzer, (2000) asserted that market oriented firms obtain organizational learning from other firms. Hoe (2008) further argued that organizational learning can be enhanced by acquiring, disseminating and utilizing market knowledge, which is more externally focused on customers and competitors. Other scholars (Kurtinaitiene 2005; Kamya et al; 2010) identified a positive relationship between market orientation and organizational learning. We therefore propose the first hypothesis;

H1: Market orientation improves organizational learning 
Market orientation and supply chain management strategy: The dimensions of supply chain management strategy according to Wisner (2003) include, creating a greater level of trust throughout the supply chain, identifying and participating in additional supply chains, establishing more frequent contact with supply chain members, creating a compatible supply chain communication and involving all supply chain members in firm's product/service marketing plans. Mentzer et al. (2008) stipulated that supply chain strategies depend on a close interaction with in-company marketing and sales resources, processes and skills. Wisner (2003) established that supplier management and customer relationship strategy, which are consistent with the market orientation, have a positive impact on supply chain management strategy. Green et al; (2006) also found out that marketing orientation relates positively and significantly to supply chain management strategy. Min and Mentzer (2000) argued that marketing orientation plays a fundamental role in implementing supply chain management. This is in line with Tukamuhabwa et al; (2011) who also identified a positive relationship between market orientation and supply chain management strategy. Min and Mentzer (2007) further asserted that market orientation improves supply chain management through supply chain orientation. We therefore propose the second hypothesis;

\section{H2: Market orientation affects supply chain management strategy}

Organizational learning and supply chain performance: The new skills required by firms to face the uncertainties of the new environment are acquired through organizational learning (Bhatnagar, 2006). Grant (1996) argued that knowledge, and the capacity to create it through learning is a key productive resource in terms of contribution to value added, strategic significance, and competitive advantage. Hult et al., (2004) maintained that knowledge-sharing between distributors and their suppliers is intended to increase their supply chain performance in terms of costs of serving, cycle time, coordination of activities and competitive advantage. Grant, (1996), also added that organizational learning from their supply chains' relationship improves their ability to perform their roles more efficiently. Brown and Hendry as cited in Min and Mentzer (2000) argued that a combination of organizational learning and working better with suppliers in supply chain management improves information exchange, which improves processes for cost savings and supply chain performance. Cantner et al; (2009) as cited by Kamya et al ; (2010) argue that the performance of knowledge organizations in the market is expected to be more superior to that of the traditional organizations. In addition, Lane et al., (2001) as cited in Miguel et al; (2010) asserted that inter- firm learning develops a critical mechanism that facilitates coordination and supply chain performance. Miguel et al; (2010) further acknowledged that knowledge sharing and learning have a positive influence on the supply chain performance. This is further re-echoed by Russell et al; (2008) who asserted that the application of knowledge has important implications for the focal firm and supply chain performance. We therefore hypothesize as follows;

\section{H3: Organizational learning improves supply chain performance}

Market orientation and supply chain performance: Rungtusanatham, (2003) citing Salvador et al. (2001) argued that when firms interact with suppliers and customers regarding materials flow and quality issues, they can expect better time-related operational performances in terms of speed and delivery punctuality. Green et al; (2006) analysed Elmuti (2002) and revealed that suboptimal supply chain management performance could be due to a weak marketing orientation. As cited by Green (2006), Mason (2003) argues that effective supply chain management involves a marketing orientation and cost reduction, which improves the firm's financial performance. Cervera et al; (2001) indicated that market orientation is significantly and positively correlated with global performance. Ju"ttner et al; (2010) found out that supplier and customer relationships which are components of market orientation influence supply chain performance in terms of shorter end-to-end pipeline time, total supply chain costs and shorter lead-time. Jeong and Hong (2007) also stated that higher levels of customer-oriented supply chain practices will have a positive impact on customeroriented supply chain performance outcomes. The following hypothesis is proposed;

H4: Market orientation affects supply chain performance 
Supply chain management strategy and supply chain performance: According to Keah (2002), efficient and effective supply chain management positively affects product quality, customer service, and competitive position of a firm. Green et al; (2006) argued that supply chain management strategy correlates positively and significantly with market performance. Wisner (2003) also identified that supply chain management strategy influences firm performance. Roh, (2008) recognizes the importance of supply chain management on successful supply chain outcomes. Park and Hartley (2002) supported the notion that supply chain best practice should propagate back through the entire supply chain to improve overall supply chain performance. Tukamuhabwa et al; (2011) also found out a positive relationship between supply chain management strategy and supply chain performance. We therefore hypothesize that;

\section{H5: Supply chain management strategy improves supply chain performance}

Market orientation, trust, commitment and supply chain performance: According to Morgan and Hunt, (1994), commitment is a desire of a committed partner for the relationship, and specifically to an enduring desire to maintain a valued relationship and willingness to work to maintain it. Kwon and Suh, (2005) argued that no commitment is consummated unless the partners recognize the existence of unbroken trust. Ryu et al; (2009) also stipulated that commitment is preceded by high levels of inter organizational trust. Trust in a channel according to Bigne and Blesa, (2003) is the degree to which a firm believes that its trading partner is honest and/or benevolent. Fawcett et al; (2006) argued that commitment beyond an organization's boundaries is necessary in order to achieve Supply chain advantage. Bigne and Blesa, (2003) also indicated that behavioural dimensions of relationships in the distribution channel are still understudied and found out that the different market orientation dimensions have different effects on trust and satisfaction. Citing Siguaw et al. (1998) and Baker et al. (1999) Bigne and Blesa, (2003) indicated that market orientation positively influenced trust and commitment. Morgan and Hunt, (1994) stated that a combination of both commitment and trust produce outcomes that promote effectiveness, productivity and efficiency. Ferry et al (2007) further indicated that cooperative behaviour such as trust and Commitment influence supply chain performance. Kwon and Suh, (2005) added that the link between the level of trust and the degree of commitment among the parties, improves the overall supply chain performance. Similarly, Ryu et al; (2009) indicated that reciprocal trusting behavior and committed effort between a buyer and supplier must exist in order to enhance supply chain performance. We therefore propose that;

H6: There is a positive relationship between market orientation and trust

H7: There is a positive relationship between market orientation and commitment

H8: Trust improves commitment

H9: Commitment has a positive effect on supply chain performance.

Figure 1: Proposed conceptual framework

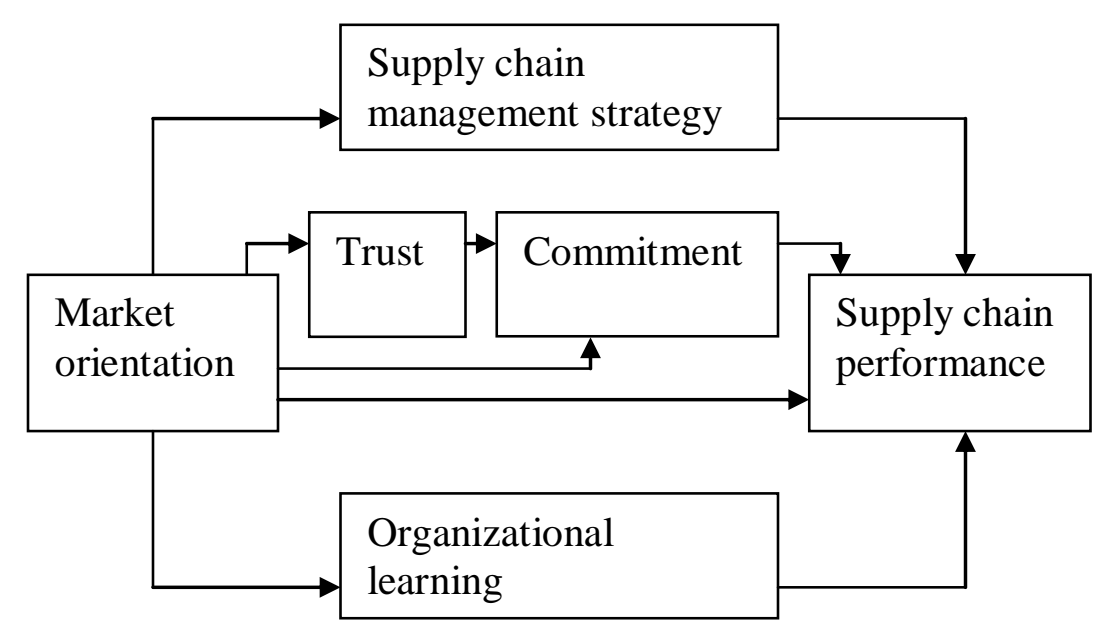




\section{Methodology}

This is a theoretical study, which based on the review of previous literature to develop research hypotheses that resulted into the proposed conceptual framework as shown in Figure 1. A further empirical research is on going in Uganda's SMEs, which will test the nature and degree of the relationships among the variables in the proposed model. In line with similar previous studies such as Ossai-Igwe and Minai (2011) and Yusof and Tahir (2011), this paper indicates the methodology that will be used in the subsequent empirical study to test the proposed model on SMEs in Uganda.

Sample: The study population will be all SMEs in Nakawa division of Kampala district as listed by the Uganda Small Scale Industries Association (USSIA). As cited by Eyaa and Ntayi (2010), Beyene (2002) and Mutula and Brakel (2006) assert that there is no generally established classification for Small- and Medium-Scale Enterprises (SM Es) in Africa This study will however adopt the classification of SMEs by the Government of Uganda which bases on the number of people employed by the firms; 5 -50 people (small) and 51- 500 people (medium) (Schiffer and Weder, 2001; Uganda Bureau of Statistics, 2003). According to Eyaa et al; (2010) there were 1500 registered SMEs in Nakawa Division (USSIA, 2007). This study will adopt the simple random sampling method and a sample size of 306 SMEs will be chosen basing on the Krejcie and Morgan (1970) sample size determination criterion.

Measurement: The Measures for the study variables will be obtained and adapted from studies undertaken by previous scholars. Supply chain performance will be measured using 11 measurement items used by Zelbst et al; (2010) which were obtained from the works of Green et al; (2008).Market orientation will be measured using scales adopted from the empirical research works of Narver and Slater (1990) who assert that market orientation consists of the three components of customer orientation, competitor orientation and inter-functional coordination. Organizational learning will be measured basing on 17 items used by Hult et al. (2000) and Hult et al (2003) which were adapted from Hult (1998). The four dimensions of organizational learning include team orientation, systems orientation, learning orientation and memory orientation, while the measurement scales for supply chain management strategy will be adopted from the scale developed by Wisner (2003). Trust will be measured using scales adapted by Bigne and Blesa (2003) who based on the works of Siguaw et al. 1998; Joshi and Stump 1999; Ganesan 1994; Morgan and Hunt 1994) (Doney and Cannon, 1997). Commitment will be measured using four items from Ryu et al; (2009) which were developed basing on the works of Morgan and Hunt (1994)

Procedure: The study will adopt cross sectional, descriptive and quantitative study designs. Primary data will be collected from respondents who will be persons in charge of or overseeing marketing, procurement or supply chain related activities using a self - administered questionnaire. The responses in the questionnaire will hinge on a 4 point Likert Scale with these responses 4 - strongly agree, 3 - agree, 2 - disagree, 1 - strongly

disagree. An even number responses will be preferred because an odd number gives room for responses of "neither agree or neither disagree" which can be easily confused for "I do not know" by respondents (Raaijmakers et al; 2000). The research instrument will be tested for reliability using the Cronbach Alpha Coefficient. The overall minimum co-efficient of 0.5 will be considered sufficient. Pre-tests will be carried to test the validity of our questionnaires. About thirty questionnaires will be distributed to employees in charge of marketing, procurement or supply chain to ensure appropriateness in wording, format and content. Data will be analysed using the Statistical Package for Social Scientists (SPSS). Descriptive statistics will be used during data analysis. Correlation analysis will be used to establish the nature and strength of the relationship between the variables while regression analysis will be used to determine the variance in supply chain performance that is explained by market orientation, organizational learning, supply chain management strategy, trust and commitment.

\section{Results and Discussion}

This paper developed a conceptual framework for supply chain performance in SMEs in Uganda. The findings indicated a positive relationship among the variables in the proposed model. In line with previous scholars (Wisner, 2003; Green et al; 2006; Tukamuhabwa et al; 2011), it was found out that market orientation has a positive influence on supply chain management strategy. Indeed, when a firm has better market orientation 
in terms of supplier management and customer relationship strategy, it will improve the level of trust throughout the supply chain. It will also help a firm in identifying and participating in additional supply chains, establishing contact that is more frequent with supply chain members, creating a compatible supply chain communication and involving all supply chain members in its product/service marketing plans. The study also revealed that market orientation improves organizational learning. Consistence with Hurley and Hult (1998), Vieira (2010) and Min and Mentzer, (2000), an increase in a firm's market orientation, will necessitate improvement in its learning. Aspects of market orientation such as inter-functional coordination present a favourable atmosphere for organizational learning. The study also found out that market orientation improves trust and commitment (Baker et al. 1999; Bigne and Blesa, 2003).As confirmed by Tukamuhabwa et al (2011), Hult et al., (2004), Grant, (1996), Min and Mentzer (2000) and Miguel et al; (2010), the study further revealed that market orientation, commitment, supply chain management strategy and organizational learning improve supply chain performance. Market oriented firms with high level of commitment, better supply chain strategies and higher levels of organizational learning will have better supply chain performance than those that do not espouse these variables.

\section{Conclusion and Recommendations}

This paper examined supply chain performance basing on its relationship with marketing in order to partly fill the existing knowledge holes. Through review of the previous literature, a conceptual model was proposed. In this framework, a positive relationship was established between market orientation, organizational learning, supply chain strategy, trust and commitment and supply chain performance. This model will be utilized to conduct an empirical study of explaining supply chain performance of SMEs in Uganda by establishing the strength of the relationships among the variables aforementioned. It is also hoped that future researchers will use the proposed framework to replicate the study in other sectors and countries. This study will also help SMEs to understand how to improve the performance of their supply chains by strengthening their market orientation. Through unearthing the constructs of trust, commitment, supply chain management strategy and organizational learning, SMEs will comprehend these variables better and be able to boost them for better performance of their supply chains.

Limitations and suggestions for further research: Like other studies, this study is not without limitations for instance, the proposed conceptual framework does not exhaust all antecedents of supply chain performance. Future researchers can extend this model to include other variables such as collaboration, supply chain innovation, firm integration and supply chain linkages. Secondly, this research is intended for SMEs, which differ from large organizations. The results may not represent large organisations. Future researchers could extend this model into large organizations so as to have a more balanced view. Thirdly, this study will be conducted in Nakawa division of Kampala. The results of this study may not be representative of all SMEs in Uganda. Further research is needed that incorporates other SMEs in other areas of Uganda

\section{References}

Antony, J. P. \& Bhattacharyya, S. (2010). Measuring organizational performance and organizational excellence of SMEs - part 2. An empirical study on SMEs in India Measuring Business Excellence, 14(328), 10351052.

Baker, T. L., Simpson, P. M. \& Siguaw, J. A. (1999).The impact of suppliers' perceptions of reseller market orientation on key relationship constructs. Journal of the Academy of Marketing Science, 27(1), 50-57.

Banomyong, R. \& Supatn, N. (2011). Developing a supply chain performance tool for SMEs in Thailand. Supply Chain Management: An International Journal, 16(1), 20-31.

Barney, J. (1991). Firm resources and sustainable competitive advantage. Journal of management, 17(1), 99120.

Bhatnagar, J. (2006). Measuring organizational learning capability in Indian managers and establishing firm performance linkage. An empirical analysis. The Learning Organization, 13(5), 416-433.

Beyene, A. (2002). Enhancing the competitiveness and productivity of small and medium scale enterprises in Africa: An analysis of different roles of national governments through improved services. African Development, 27 (3), 130 - 156. 
Bigne, E. \& Blesa, A. (2003). Market orientation, trust and satisfaction in dyadic relationships: a manufacturerretailer analysis. International Journal of Retail \& Distribution Management, 31(11), 574-590.

Calipinar, H. (2007). A Theoretical Model Proposal in Supply Chain Management for Turkish SMEs. J. Pr. and Per. Mgt, 5(2), 90-98.

Cantner, U., Joel, K. \& Schmidt, T. (2009). The use of knowledge management by German innovators. Journal of Knowledge management, 13(4), 187-203.

Cervera, A., MollaÂ, A. \& SaÂnchez, M. (2001). Antecedents and consequences of market orientation in public organisations. European Journal of Marketing, 35(11/12), 1259-1286.

Confederation of Tanzania industries (2009). SMEs market access through private and public procurement and linkages. Policy position paper

Doney, P. \& Cannon, J. P. (1997). An examination of the nature of trust in buyer-seller relationships. Journal of Marketing, 61(2), 35-51.

Elmuti, D. (2002). The perceived impact of supply chain management on organizational effectiveness. Journal of Supply Chain Management, 38(3), 49-57.

Eyaa, S. \& Ntayi, J. M. (2010). Procurement Practices and Supply Chain Performance of SMEs in Kampala. Asian Journal of Business Management, 2(4), 82-88.

Eyaa, S., Ntayi, J. \& Namagembe, S. (2010). Collaborative relationships and SME supply chain performance. World Journal of Entrepreneurship, Management and Sustainable Development, 6(3).

Farrelly, F. \& Quester, P. (2003). The effects of market orientation on trust and commitment: The case of the sponsorship business-to-business relationship. European Journal of Marketing, 37(3/4), 530 - 553.

Fawcett, S. E., Ogden, J. A., Magnan, G. M. \& Cooper, M. B. (2006). Organizational commitment and governance for supply chain success. International Journal of Physical Distribution \& Logistics Management, 36(1), 006, 22-35.

Ferry, J., Parton, K. \& Rodney, C. (2007). Supply Chain Practice, Supply Chain Performance Indicators and Competitive Advantage of Australian Beef Enterprises: A Conceptual Framework. Australian Agricultural and Resource Economics Society (AARES 51st Annual Conference).

Ganesan, S. (1994).Determinants of long-term orientation in buyer-seller relationships. Journal of Marketing, $58(2), 1-19$.

Grant, R. M. (1996). Toward a knowledge-based theory of the firm. Strategic Management Journal, 17, 232-49.

Green, J., Kenneth, W., Whitten, D. \& Anthony, R. I. (2008). The impact of logistics performance on organizational performance in a supply chain context. Supply Chain Management: An International Journal, 13/4, 317-327.

Green, J., Kenneth, W., McGaughey, R. \& Casey, M. K. (2006). Does supply chain management strategy mediate the association between market orientation and organizational performance? Supply Chain Management: An International Journal, 11(5), 407-414.

Gunasekaran, A., Patel, C. \& McGaughey, R. E. (2004). A framework for supply chain performance measurement. Int. J. Production Economics, 87, 333-347.

Hamisi, S. (2011). Challenges and opportunities of Tanzanian SMEs in adapting supply chain management African Journal of Business Management, 5(4), 1266-1276.

Hoe, S. L. (2008). Benefiting from customer and competitor knowledge. A market-based approach to organizational Learning. The Learning Organization, 15(3), 240-250.

Hult, G. T. M., Hurley, F. B., Giunipero, C. L. \& Nichols, L. E. J. (2000). Organizational learning in global purchasing. A model and test of internal users and corporate buyers. Decision sciences. 31(2).

Hult, G. T. M., Ketchen, D. J. \& Slater, S. F. (2004). Information processing, knowledge development and strategic supply chain performance. Academy of Management Journal, 47(2), 241-253.

Hult, G., Tomas, M., Ketchen, J., David, R. \& Arrfelt, M. (2007). Strategic supply chain management: Improving performance through a culture of competitiveness and knowledge development. Strategic Management Journal, 28, 1035-1052.

Hult, G., Tomas, M., Ketchen, J., David, J., Nichols, J. \& Ernest, L. (2003). Organizational learning as a strategic resource in supply management. Journal of operations management, 21, 541-556.

Hurley, F. R. \& Hult, G. T. (1998). Innovation, market orientation and organizational learning. An integration and empirical examination. Journal of marketing, 62, 42-54.

Jeong, J. S. \& Hong, P. (2007). Customer orientation and performance outcomes in supply chain management. Journal of Enterprise Information Management, 20(5), 578-594. 
Joshi, A. W. \& Stump, R. L. (1999). The contingent effect of specific asset investments on joint action in manufacturer-supplier relationships: an empirical test of the moderating role of reciprocal asset investments, uncertainty, and trust. Journal of the Academy of Marketing Science, 27(3), 291-305.

.Ju"ttner, U., Christopher, M. \& Godsell, J. (2010). A strategic framework for integrating marketing and supply chain strategies. The International Journal of Logistics Management, 21(1), 104-12.

Kamya, M. T., Ntayi, J. M. \& Ahiauzu, A. (2010). Knowledge management and competitive advantage: The interaction effect of market orientation. African Journal of Business Management, 4(14), 2971-2980.

Keah, C. T. (2002). Supply chain management: practices, concerns, and performance issues. Journal of Supply Chain Management, 38(1), 42-53.

Krejcie, R.V. and Morgan, D.W. (1970). Determining sample size for research activities. Education Psychology Measurement, 30, 607-610.

Kwon, I. G. \& Suh, T. (2005). Trust, commitment and relationships in supply chain management: a path analysis. Supply Chain Management: An International Journal, 10(1), 26-33.

Kurtinaitiene, J. (2005). Marketing orientation in the European Union mobile telecommunication market. Marketing Intelligence \& Planning, 23(1), 104-113.

Lennon, A. \& Wollin, A. (2001). Learning organisations: Empirically investigating metaphors. Journal of intellectual capital, 2(4), 401-422.

Lane, P. J., Salk, J. E. \& Lyles, M. A. (2001). Absorptive capacity, learning, and performance in international joint Ventures. Strategic Management Journal, 22(12), 1139-61.

Lewis, E. (2005). Now is SMEs' time to compete on-demand supply chain solutions are affordable for the small distributor, Industrial Distribution, September.

Manuel, R. D., Tomas, F. \& Espino, R. (2006). Developing relational capabilities in hotels. International Journal of Contemporary Hospitality Management, 18(1), 25-40.

Mason, K. J. \& Harris, L. C. (2006). Market orientation emphases: an explanation of macro, meso, and micro drivers, Mark. Intelligence planning, 24(6), 552-571.

Mentzer, J. T., Stank, T. P. \& Esper, T. L. (2008). Supply chain management and its relationship to logistics, marketing, production, and operations management. Journal of Business Logistics, 29(1), 31-46.

Miguel, H. E., Augusto, R. O. \& Manuel, S. P. (2010). Inter-organizational governance, learning and performance in supply chains. Supply Chain Management: An International Journal, 15(2), 101 - 114.

Min, S. \& Mentzer, J. T. (2000). The role of marketing in supply chain management. International journal of physical distribution management, 30(9), 765-787.

Min, S., Mentzer, J. T. \& Robert, T. L. (2007). A market orientation in supply chain management. J. of the Acad. Mark. Sci, 35, 507-522.

Morgan, R. M. \& Hunt, S. D. (1994).The commitment- trust theory of relationship marketing. Journal of Marketing, 58(3), 20-38.

Mutula, S. M. \& Brakel, P. (2006). E-Readiness of SMEs in the ICT sector in Botswana with respect to information access. Electronic Library, 24(3), 402-417.

Narver, C. J. \& Slater, F. S. (1990).The effect of a marketing orientation on business profitability. Journal of marketing, 54 (4), 20-35.

Narver, J. C., Slater, S. F. \& MacLaclan, D. (2004). Responsive and proactive market orientation and new product success. J. Prod. Innovation. Management, 12(5), 334-44.

Ntayi, J., Gerrit, R. \& Eyaa, S. (2009). Supply chain swiftness in a developing country: The case of Uganda small and medium sized enterprises. E-Journal of Business and Economic Issues, 4(1).

Ntayi, J. M. \& Eyaa, S. (2010). Collaborative Relationships, Procurement Practices and Supply Chain Performance: The Case of Small and Medium Enterprises in Uganda. In: Sonny, N. and A. Allam (Eds.), African Entrepreneurship in Global Contexts: Enterprise Solutions for Sustainable Development. World Sustainable, London, Chap: 7.

Okello-Obura, C., Minishi-Majanja, M. K., Cloete, L. \& Ikoja-Odongo, R. J. (2008). Sources of business information and means of access used by SMEs in Uganda: The case of Northern Uganda. Lib. Inform. Science. Res. Electron. J., 18(1), 1-13.

Onugu, N. B. A. (2005). Small and Medium Enterprises (SMEs) in Nigeria: Problems and prospects. St. Clements University, Nigeria (Unpublished Dissertation for a Doctor of Philosophy in Management Award).

Ossai-Igwe, E. L. \& Minai, M. S. (2011). The conceptual framework of entrepreneur and self-management. International Journal of Business and Social Science, 2(20), 180-185. 
Park, S. \& Hartley, J. L. (2002). Exploring the effect of supplier management on performance in the Korean automotive supply chain. Journal of Supply Chain Management, 38(2), 46-52.

Ponomarov, S. Y. \& Holcomb, M. C. (2009). Understanding the concept of supply chain resilience. The International Journal of Logistics Management, 20(1), 124-143, 665-682.

Quayle, M. (2003). A study of supply chain management practices in UK industrial SMEs", Supply Chain Management - An International Journal, Vol. 8 No. 1, pp. 79-86

Raaijmakers, Q. A. W., Van Hoof, A., Hart, T., Verbogt, A. M. F. T. \& Vollebergh, M. A. W. (2000). Adolescents mid-point responses on Likert-type scale items: Neutral or missing values? International Journal of public opinion research, 12, 208-217.

Roh, J. J., Hong, P. \& Park, Y. (2008). Organizational culture and supply chain strategy: a framework for effective information flows. Journal of Enterprise Information Management, 21(4), 361-376.

Rungtusanatham, M., Salvador, F., Forza, C. \& Choi, Y. T. (2003). Supply-chain linkages and operational performance: A resource-based-view perspective. International Journal of Operations \& Production Management, 23(9), $1084-1099$.

Russell, T. C., Larry, G., Robert, H. \& Susan, K. W. (2008). Antecedents and outcomes of supply chain effectiveness: an exploratory investigation. Journal of managerial issues, 20(2).

Ryu, I. l., SoonHu, S. \& Koo, C. (2009). The role of partnership in supply chain performance. Industrial Management \& Data Systems, 109(4), 496-514.

Salvador, F., Forza, C., Rungtusanatham, M. \& Choi, T. Y. (2001). Supply chain interactions and time-related performances: an operations management perspective. International Journal of Operations \& Production Management, 21, 461-75.

Slater, F. S. \& Narver, C. J. (1995). Market orientation and the learning organization, Journal of marketing, 59 (3), 63-74.

Schiffer, M. \& Weder, B. (2001). Firm size and the business environment. Worldwide Survey Results, Discussion paper 43, World Bank, Washington.

Siguaw, J. A., Simpson, P. M. \& Baker, T. L. (1998).Effects of supplier market orientation on distributor market orientation and the channel relationship: the distributor perspective. Journal of Marketing, 62(3), 99111.

Tan, Y. C., Mavondo, F. \& Worthington, S. (2011). Organizational capabilities and relationship quality Performance implications for palm oil processors in Malaysia. Asia Pacific Journal of Marketing and Logistics, 23(2), 152-164.

Thakkar, J., Kanda, A. \& Deshmukh, S. G. (2008). Supply chain management in SMEs: development of constructs and propositions. Asia Pacific Journal of Marketing and Logistics, 20(1).

Tukamuhabwa, B. R., Eyaa, S. \& Friday, D. (2011). Mediating variables in the relationship between market orientation and supply chain performance: A theoretical approach. International journal of business and social science, 2(22), 99-107.

Uganda Bureau of Statistics, (2003).Annual report

Vieira, V. A. (2010). Antecedents and Consequences of Market Orientation: a Brazilian Meta-Analysis and an International Mega-Analysis. Brazillian Administrative review, 7(1), 40-58.

Wisner, J. D. (2003). A structural equation model of supply chain management strategies and firm performance. Journal of Business Logistics, 24(1), 1-26.

Yusof, J. M. \& Tahir, I. M. (2011). Spiritual Leadership and Job Satisfaction: A Proposed Conceptual Framework. Information Management and Business Review, 2(6), 239-245.

Zelbst, P. J., Green, J. K. W., Sower, V. E. \& Reyes, P. (2009). Impact of supply chain linkages on supply chain performance. Industrial Management \& Data Systems, 109 (5).

Zelbst, P. J., Green, J. K. W., Sower, V. E. \& Baker, G. (2010). RFID utilization and information sharing: the impact on supply chain performance. Journal of Business \& Industrial Marketing, 25(8), 582-589.

Zhou, Y., Chao, P. \& Huang, G. (2009). Modeling market orientation and organizational antecedents in a social marketing context: evidence from China. Inter. Mark. Rev, 26(3), 256-274. 